\title{
Analysis Of The Political Marketing Success Of The Winning National Party With Local Affiliated Party In Aceh
}

\author{
Wahyuddin ${ }^{1}$, Fuadi $^{2}$, Falahuddin ${ }^{3}$, Hanif $^{4}$ \\ 1,2,3,4 Fakultas Ekonomi Dan Bisnis Universitas Malikussaleh \\ Email Corespondent : fuadi.msm@unimal.ac.id
}

\begin{abstract}
:
The purpose of this study was to determine the level of success of the political marketing of the victory of the national party with its affiliated local party in Aceh. The political marketing concept of product, promotion, price and place is used in this study. Primary data was obtained by using a questionnaire. The research locations are two districts in the province of Aceh, namely Bireuen Regency and Pidie Jaya Regency, while sampling using Maximum Likelihood $(M L)$ in the estimation model requires the use of a minimum sample size of 100. By setting the number of samples for each voter national parties and local party voters. The sample will be taken at convenience from each research location. The result of the study of the coefficient of determination $(R 2)$ is 0.269 . This means that $26.9 \%$ changes in the dependent variable, namely the Decision to Choose a National Party, can be explained in the independent variables, namely Product, Promotion, Price, and Place. While the remaining $73.1 \%$ is explained by other variables outside the variables studied. This shows that the contribution of the independent variable has little impact on the dependent variable. While the results of the coefficient of determination of the Decision to Choose a Local Party is 0.672. This means that $67.2 \%$ changes in the dependent variable, namely the Decision to Choose a Local Party, can be explained in the independent variables, namely Product, Promotion, Price, and Place. While the remaining $32.8 \%$ is explained by other variables outside the variables studied. This shows that the contribution of the independent variable has an impact on the dependent variable.
\end{abstract}

Keywords : Political Marketing, Election Decision, Political Party.

\begin{abstract}
Abstrak:
Tujuan dari penelitian ini adalah untuk mengetahui tingkat keberhasilan marketing politik kemenangan partai nasional dengan partai lokal afiliasinya di aceh. Konsep pemasaran politik yaitu produk, promosi, harga dan tempat digunakan dalam penelitian ini. Data primer diperoleh dengan menggunakan kuesioner. Target lokasi penelitian pada dua Kabupaten yang terdapat dalam wilayah provinsi Aceh yaitu Kabupaten Bireuen dan Kabupaten Pidie Jay adapun dalam pengambilam sampel dengan menggunakan Maximum Likelihood (ML) pada model estimasi, mensyaratkan penggunaan jumlah minimum sampel sebanyak 100. Dengan menetapkan jumlah sampel masingmasing pemilih partai nasional dan pemilih partai lokal. Sampel tersebut akan diambil secara convenience dari setiap lokasi penelitian. Hasil penelitian Koefesien Determinasi $\left(\mathrm{R}^{2}\right)$ adalah sebesar 0,269 . Hal ini berarti $26,9 \%$ perubahan-
\end{abstract}


Party In Aceh

Wahyuddin $^{1}$, Fuadi $^{2}$, Falahuddin ${ }^{3}$, Hanif $^{4}$

perubahan dari variabel terikat yaitu Keputusan Memilih Partai Nasional dapat dijelaskan dalam variabel bebas yakni Produk, Promosi, Harga, dan Tempat. Sedangkan selebihnya 73,1\% dijelaskan oleh variabel lain diluar variabel yang diteliti. Hal ini menunjukkan kontribusi dari variabel bebas tidak begitu memberi dampak pada variabel terikat. Sedangkan hasil keofesien determinasi Keputusan Memilih Partai Lokal adalah sebesar 0,672. Hal ini berarti 67,2\% perubahan-perubahan dari variabel terikat yaitu Keputusan Memilih Partai Lokal dapat dijelaskan dalam variabel bebas yakni Produk, Promosi, Harga, dan Tempat. Sedangkan selebihnya 32,8\% dijelaskan oleh variabel lain diluar variabel yang diteliti. Hal ini menunjukkan kontribusi dari variabel bebas begitu memberi dampak pada variabel terikat.

Keywords : Marketing Politik, Keputusan Memilih, Partai Politik.

\section{INTRODUCTION}

In Indonesia, political parties are a forum for people's political participation as an embodiment of the 1945 Constitution, article 28. Freedom of association and assembly, expressing thoughts orally and in writing and so on are stipulated by law". This is then regulated by the Law of the Republic of Indonesia Number 2 of 2008 concerning political parties. The law states that what is meant by a political party is a political organization formed by a group of citizens of the Republic of Indonesia voluntarily on the basis of the same will and ideals to fight for the interests of members, society, nation and state through elections.

With political parties as well, strife and agreement can become in arranging and developing the community. The conflicts that are created are not necessarily used as an excuse to divide the party, but the conflicts that arise are sought for consensus to create a healthy party. Reforms are carried out by the Indonesian people in all aspects of the country's life, including reforms in the political field. As the word itself means, political reform simply means reshaping the political format to better reflect the principles of democracy and the principle of popular sovereignty (Arep et al., 2003). One way to realize democracy itself is by holding general elections. Beginning in 2009, the government's policy in politics, especially for the province of Aceh, has stipulated that there are opportunities for the people of Aceh to form local parties and participate in elections in the area. It is an interesting phenomenon in the application of the marketing mix in the economic concept into the political process. Its implementation is known as political marketing.

Political marketing is a branch of science that has recently grown, in research O'Shaughnessy, (1990) in Butler \& Collins, (1994) proposes that research and discussion on political marketing focus more on how considerations of marketing aspects become the orientation of political parties. so that the political process and electoral behavior will produce new findings that broaden understanding from a marketing point of view and can produce new thoughts and findings in the field of marketing.
Political parties in relation to voters are an affiliation, where if voters continue to connect with their parties, it is certain that their loyalty will be formed.

For this reason, it has become a consequence for a political party to develop a special strategy early on in determining the objectives of its public relations program so that the party's image will still have a place in the hearts of its supporters, even though the party figure will eventually disappear and no longer be accepted by the public. Another thing to note is the ability to analyze the image (image analysis) of the party. This activity is intended to build and maintain the party's reputation in the eyes of the public. The image of political parties (political parties) in the minds of individuals and the public and the general public is very important to take into account, both by political party administrators, cadres, partisans, and interest groups. The image of political parties by marketing mix variables in shaping voter loyalty is a new thing that needs to be researched so that voter loyalty can be realized in the general election period in the future.

Base on explanation above, the authors are interested in conducting research on the above problems by taking the title of the study: Analysis of the Success Rate of Political Marketing Success of the National Party with its Affiliated Local Parties in Aceh.

\section{LITERATURE REVIEW \\ Political Marketing}

Political marketing is a term used more frequently in academia and practice in Europe than in the United States (Saper et al., 2005). The distinction between political marketing, political management, or political communication is not always clear and is often obscured by overlapping interpretations. However, political marketing often evokes negative feelings and is considered harmful to politics and democratic systems (Dermody et al., 2010; Lilleker, 2006; Moloney \& Colmer, 2001). The definition of political marketing with the same essence is also expressed by namely, the use of marketing methods in the political field. 


\section{Political Marketing Concept}

Harris (2001), defines political marketing as a general desire that is equated with techniques used in an effort to invite voters in campaigns to promote both their politicians and their policies. The application of the political marketing mix in the political stage is something that cannot be abandoned.

The concept of political marketing will support the process of creating a political communication strategy between political parties or candidates with the character of the target community. Niffenegger in Wring, (1997) classifies the concept of political marketing into 4, namely: product, price, place and promotion.

\section{Product}

According to Wring, (1997) the main product of political parties is the party platform which contains concepts, identities, ideologies and work programs, but the platform cannot determine the selling price of the political party. Political parties need an image to foster a positive impression of society towards political parties. The products sold are brands that are owned by variables involved in political communication to constituents, namely candidates, success teams and political parties that carry. Candidates can cultivate a positive image of themselves, both in the campaigns they carry out and events (events) in the past.

\section{Promotion}

According to (Wring, 1997), the principles of promotion through the media are divided into two parts, namely paid and free media. Paid media that are commonly used are advertisements in the form of posters, forms that are distributed to the public or use prime time on television and radio. In addition to these media, you can use media that are currently developing, such as direct mail, direct marketing, SMS or telephone.

\section{Price}

According to (Firmanzah, 2007), divides 3 price factors in the political marketing mix, namely:

a. The economical price is all the costs incurred by the campaign team to carry the proposed candidate. Starting from the cost of advertising, meetings, consolidation, intimate meetings with community leaders, and others. b. Psychological price, is the psychological perception of voters towards the character. This is in the form of convenience or inconvenience for voters to vote for people with ethnic, religious or other backgrounds.

c. Regional images, in the form of images that have been given by voters to candidates. So far, the candidate has high nationalism or not, it gives a positive image for the nation or not. For the local context, this can be in the form of a candidate's concern for his area.

\section{Place}

The most important thing in the placement is on the network that is built to the lowest point in the regions. Many political parties in the UK organize their membership and political machinery on a regional and local basis.(Wring, 1997), in general, explains that the place factor consists of 3, namely local network, canvassing and tour leader, namely:

a. Local networks are local actions that have been or are being carried out by candidates, candidate success teams and party cadres who carry the candidate's name with the aim of establishing good relations between the candidate and the voting community, so as to form a positive image of the candidate himself.

b. Canvassing is an effort to gather the masses and collect them in existing ballots based on criteria made by parties or candidates.

c. The leader tour includes the involvement of party cadre candidates, as well as the campaign team in community activities. This can be in the form of visits or gatherings of candidates in both social and religious organizations.

\section{Voter's Decision}

In principle, purchasing decisions and elections made by consumers and voters in the political world are not much different. The difference that is seen is striking in the dominance of the candidate factor, so the statement from Bergman and Wickert (1999) in Nursal, (2004), "the man is the message" or "the leading candidate is the platform".

Futhermore, a voter will make a decision to exercise his/her right to vote for several reasons:

1. There is a sense of interest and satisfaction with the candidate. 
2. The number of candidates. This reason arises because voters have many choices.

3. Media shows that present positive things that are done by political parties.

4. The belief that the process of selecting political leaders is as important as the monitoring process. This belief becomes important as evidence that the public is not apathetic, or not pessimistic about the process of selecting political leaders.

\section{Political parties}

In general it can be said that a political party is an organized group whose members share the same orientation, values and ideals. The activities of a person in a political party is a form of political participation.

These activities include voting in general elections, becoming party members, sitting in political institutions such as the People's Representative Council or communicating with people's representatives sitting in that body, campaigning, and so on.

Article 1 of Law Number 31/2002 states that what is meant by political parties are political organizations formed by a group of citizens of the Republic of Indonesia voluntarily on the basis of equal will and ideals to fight for the interests of members, society and the state through general elections. According to Surbakti, (1992). This provision implies that a political party can be said to be a representation of ideas about the state and society as aspired by a group of citizens who are fought for through elections in their own (local) territory.

In the Government Regulation of the Republic of Indonesia No. 20 in 2007 concerning Local Political Parties in Aceh, it is written that a local political party is a political organization formed by a group of Indonesian citizens domiciled in Aceh voluntarily with the same will and ideals to fight for the interests, members, society. , the nation and the state through the Aceh People's Representative Council (DPRA) / Regency / City People's Representative Council (DPRK), the Governor and Deputy Governor, as well as the Regent and Deputy Regent / Mayor and Deputy Mayor.

\section{RESEARCH METHODS}

\section{Research Location and Object}

This research will be carried out in the province of Aceh with the target of research locations in two districts in the Nanggroe Aceh Darussalam region. The districts that are the location of this research are Bireuen Regency and Pidie Jaya Regency

\section{Population}

Sugiono, (2014), concluded that the population is a general area consisting of subjects who have quality and character and are determined by researchers to be used as learning which will then be drawn a conclusion from the results of their research. The population in this study are voters who exercise their voting rights in the provincial legislative elections (DPRA) which are residents of Bireuen Regency and Pidie Jaya Regency which are distinguished by national party voters and local party voters.

\section{Research Sample}

The sample is part of the number and character possessed by a population, the most important thing is that the sample taken must be able to represent the population (Sugiono, 2014). 100 people are used of Maximum Likelihood (ML) in the estimation model requires the minimum number sample. (Ghozali, 2013). as well, recommends the number of samples between $100-200$ to be used. The researcher determined that the number of samples to be used in this study was 100 samples for each of the national party voters and local party voters. The sample will be taken at convenience from each research location.

\section{Data analysis method}

In this research, the data analysis equipment used is Multiple Linear Regression analysis. Furthermore, it will be equipped with Correlation Coefficients and Determinants. In order for the results of the analysis to be meaningful, a test procedure was carried out using the ttest (partial) and F-test (simultaneous) approaches.

\section{Data analysis method \\ 1. National Party Voter Data Validity and Reliability a. National Party Data Validity}

The validity test in this study was carried out statistically, namely by using the Pearson ProductMoment Coefficient of Correlation test. Validity test assessment criteria, if $r$ count $>r$ table at a significance level of 0.05 , it can be said that the questionnaire item is valid but if the value of $r$ count $<r$ table at a significance level of 0.05 , it can be said that the questionnaire item is invalid. Based on the calculation of the Pearson ProductMoment Coefficient of Correlation that all question items are valid, all indicators (correlation value) are obtained > 0.382 which means that all $\mathrm{X}$ and $\mathrm{Y}$ indicators are valid. From the results obtained, it can be concluded that the independent and dependent variable indicators are declared valid. 


\section{b. Validitas Data Partai lokal}

Pengujian validitas dalam penelitian ini dilakukan secara statistik, yaitu dengan menggunakan uji Pearson Product-Moment Coeffisient of Corelation. Kriteria penilaian uji validitas, apabila $r$ hitung $>r$ tabel pada taraf signifikansi 0.05 , maka dapat dikatakan item kuesioner tersebut valid tetapi jika nilai $r$ hitung $<\mathrm{r}$ tabel pada taraf signifikansi 0.05 , maka dapat dikatakan item kuesioner tersebut tidak valid. Berdasarkan perhitungan Pearson Product-Moment Coeffisient of Corelation bahwa semua item pertanyaan adalah valid, didapatkan semua indikatornya (nilai korelasi) $>0.382$ yang berarti bahwa semua indikator $\mathrm{X}$ dan $\mathrm{Y}$ adalah Valid. Dari hasil yang telah didapat, dapat disimpulkan bahwa indikatorindikator variabel bebas dan terikat dinyatakan valid.

\section{c. Reliability Test}

Reliability test To know the reliability of each instrument used, the researcher used the Cronbach Alpha coefficient. An instrument is said to be reliable if it has an alpha value greater than 0.06 .

Tabel. 1

\begin{tabular}{|c|l|c|c|c|c|}
\hline \multirow{2}{*}{ No } & \multicolumn{1}{|c|}{ Variabel } & Wilayah & $\begin{array}{c}\text { Jumlah } \\
\text { Indikator }\end{array}$ & Nilai Alpha & Ket \\
\hline \multirow{2}{*}{1} & \multirow{2}{*}{ Produk $\left(\mathrm{X}_{1}\right)$} & Nasional & 3 & 0.651 & Reliabel \\
\cline { 3 - 6 } & \multirow{2}{*}{2} & Lokal & 3 & 0.811 & Reliabel \\
\hline \multirow{2}{*}{3} & \multirow{2}{*}{ Harga $\left(\mathrm{X}_{1}\right)$} & Nasional & 4 & 0.695 & Reliabel \\
\cline { 3 - 6 } & Lokal & 4 & 0.834 & Reliabel \\
\hline \multirow{2}{*}{4} & \multirow{2}{*}{ Tempat $\left(\mathrm{X}_{2}\right)$} & Nasional & 3 & 0.718 & Reliabel \\
\cline { 3 - 6 } & \multirow{2}{*}{5} & Lokal & 3 & 0.752 & Reliabel \\
\cline { 3 - 6 } & \multirow{2}{*}{ Keputusan $(\mathrm{Y})$} & Losional & 3 & 0.660 & Reliabel \\
\cline { 2 - 6 } & & Nasional & 3 & 0.791 & Reliabel \\
\cline { 2 - 6 } & Lokal & 10 & 0.686 & Reliabel \\
\hline
\end{tabular}

Source: Processed Results of 2019 Spss Data

It can be seen that the Cronbach Alpha values for the 5 (five) research variables above, namely Product, Promotion, Price, Place, and Decision to Choose are obtained respectively $(0.651),(0.695),(0.718),(0.660)$ and (0.686) or $>$ from 0.60 . Thus the data from the variables involved in this study meet the credibility of Cronbach Alpha because the alpha value is > from 0.6.

\section{Multiple Linear Regression Equation Analysis}

To determine the effect of Product, Promotion, Price, and Place on the Decision to Choose a National Party or a Local Party, data analysis was carried out through multiple regression formulations (multiple regression). The results of the SPSS multiple linear regression output can be seen in the following explanation.

\section{a. Multiple Linear Regression For National Party Voters}

\section{Regression Coefficient}

Table. 2.

Results of Regression Analysis of the Effect of Product, Promotion, Price, and Place on the Decision to Choose a National Party

\begin{tabular}{|c|c|c|c|c|}
\hline \multicolumn{5}{|c|}{ Coefficients $^{\mathrm{a}}$} \\
\hline \multirow{2}{*}{\multicolumn{2}{|c|}{ Model }} & \multicolumn{2}{|c|}{ Unstandardized Coefficients } & \multirow{2}{*}{$\frac{\text { Standardized Coefficients }}{\text { Beta }}$} \\
\hline & & $\mathrm{B}$ & Std. Error & \\
\hline \multirow[t]{5}{*}{1} & (Constant) & 3.087 & .545 & \\
\hline & Produk & .172 & .128 & .174 \\
\hline & Promosi & .119 & .099 & .104 \\
\hline & Harga & .109 & .051 & .101 \\
\hline & Tempat & .113 & .071 & .107 \\
\hline \multicolumn{5}{|c|}{ a. Dependent Variable: Keputusan } \\
\hline
\end{tabular}

The results of the regression analysis shown in table 4.18 above, can be described regression in the form of a linear equation. The form of the equation is as follows: $\mathrm{Y}=3.087+0.172 \mathrm{X}_{1}+0.119 \mathrm{X}_{2}+0.109 \mathrm{X}_{3}+0.113 \mathrm{X}_{4}$

a. A constant value of 3.087 can be interpreted that without the Product, Promotion, Price, and Place variables, the voter's decision to choose a national party is 3.087

b. The coefficient b1 value of 0.172 can be interpreted that every increase in perception of the Product variable by 1 point, it will increase voter's decision by 0.172 points.

c. The b2 coefficient value of 0.119 can be interpreted that every increase in perception of the Promotion variable by 1 point, it will increase voter's decision by 0.119 points.

d. The b3 coefficient value of 0.109 can be interpreted that every increase in perception of the price variable by 1 point, it will increase voter decisions by 0.109 points.

e. The b4 coefficient value of 0.113 can be interpreted that every increase in perception of the Place variable by 1 point, it will increase voter decisions by 0.113 points.

\section{Simultaneous Test}

From the results of the ANOVA or F test, the Fcount value of 87,851 with Ftable of 2,603 means that Fcount > Ftable with a probability of 0.000 is much smaller than 0.05 or $5 \%$ so that it can be interpreted that the Product, Promotion, Price, and Place variables simultaneously have a significant effect. on the voter's decision to choose a national party in the 2019 Provincial Election at the Bireuen and Pidie Jaya Regencies, Aceh Province.

Table. 3 


\begin{tabular}{|l|l|c|c|c|c|c|}
\hline \multicolumn{7}{|l|}{ Tabel 4.19 ANOVA $^{\text {a }}$} \\
\hline \multirow{2}{*}{ Model } & $\begin{array}{c}\text { Sum of } \\
\text { Squares }\end{array}$ & df & Mean Square & F & Sig. \\
\hline \multirow{3}{*}{1} & Regression & .343 & 4 & .086 & 87.851 & $.0000^{b}$ \\
\cline { 2 - 7 } & Residual & 9.579 & 95 & .101 & & \\
\cline { 2 - 7 } & Total & 9.922 & 99 & & & \\
\hline \multicolumn{2}{|l|}{ a. Dependent Variable: Keputusan } \\
\hline \multicolumn{2}{|l|}{ b. Predictors: (Constant), Tempat, Promosi, Harga, Produk } \\
\hline
\end{tabular}

\section{Partial Test}

According to the results of calculations using SPSS, it can be concluded that the variables included in the regression model, namely the Product, Promotion, Price, and Place variables partially can be explained as follows:

Table. 4

\begin{tabular}{|c|c|c|c|c|c|}
\hline \multicolumn{6}{|c|}{ Tabel 4.20 Coefficients ${ }^{\mathrm{a}}$} \\
\hline \multirow[b]{2}{*}{ Model } & \multicolumn{2}{|c|}{$\begin{array}{l}\text { Unstandardized } \\
\text { Coefficients } \\
\end{array}$} & \multirow{2}{*}{$\begin{array}{c}\begin{array}{c}\text { Standardized } \\
\text { Coefficients }\end{array} \\
\text { Beta }\end{array}$} & \multirow[b]{2}{*}{$t$} & \multirow[b]{2}{*}{ Sig. } \\
\hline & B & Std. Error & & & \\
\hline 1 (Constant) & 3.087 & .545 & & 5.669 & .000 \\
\hline \begin{tabular}{|l|} 
Produk \\
\end{tabular} & .172 & .128 & .174 & 6.347 & .000 \\
\hline Promosi & .119 & .099 & .104 & 5.191 & .002 \\
\hline Harga & .109 & .051 & .101 & 4.172 & .009 \\
\hline Tempat & .113 & .071 & .107 & 1.182 & .059 \\
\hline
\end{tabular}

a. The results of the research on the Product variable (X1) obtained tcount $=6,347$ while ttable was 1,986 . These results indicate that tcount $>$ ttable with a significance of 0.000 or a probability below 0.05 . Thus the results of statistical calculations show that partially the Product variable (X1) has a significant effect on the National Party Election Decision (Y) variable.

b. The results of the research on Promotional Variables (X2) obtained tcount $=5.191$ while ttable was 1.986 . These results indicate that tcount $>$ ttable with a significance of 0.002 or a probability below 0.05 . Thus, the results of statistical calculations show that partially the Promotional Variable (X2) has a significant effect on the Decision to Choose a National Party (Y) variable.

c. c. The results of the study on the Price Variable (X3) obtained tcount $=4.172$ while ttable was 1.986 . These results indicate that tcount $>$ ttable with a significance of 0.009 or a probability far below 0.05 . Thus the results of statistical calculations show that partially the Price Variable (X3) has a significant effect on the National Party Choosing Decision variable (Y).

d. d. The results of the research on the Place Variable (X4) obtained tcount $=1.182$ while ttable was 1.986 . These results indicate that tcount $<$ ttable with a significance of 0.059 or a probability above 0.05 . Thus the results of statistical calculations show that partially the Place Variable (X4) has no significant effect on the Variable Decision to Choose a National Party (Y).

\section{Coefficient of Determination (R2)}

From the SPSS model summary display, the coefficient of determination is 0.269 . This means that $26.9 \%$ changes in the dependent variable, namely the Decision to Choose a National Party, can be explained in the independent variables, namely Product, Promotion, Price, and Place. While the remaining $73.1 \%$ is explained by other variables outside the variables studied. This shows that the contribution of the independent variable has little impact on the dependent variable.

\section{b) Multiple Linear Regression For Local Party Voters 1) Regression coefficient}

Table. 5

Regression Analysis result of the Effect of Product, Promotion, Price, and Place on the Decision to

Choose a Local Party

\begin{tabular}{|c|c|c|c|}
\hline \multicolumn{4}{|c|}{ Coefficients ${ }^{\mathrm{a}}$} \\
\hline \multirow[b]{2}{*}{ Model } & \multicolumn{2}{|c|}{ Unstandardized Coefficients } & \multirow{2}{*}{$\frac{\text { Standardized Coefficients }}{\text { Beta }}$} \\
\hline & B & Std. Error & \\
\hline \begin{tabular}{|l|l|}
1 & (Constant) \\
\cline { 2 - 2 }
\end{tabular} & 3.087 & .545 & \\
\hline Produk & .172 & .128 & .174 \\
\hline Promosi & .119 & .099 & .104 \\
\hline Harga & .109 & .051 & .101 \\
\hline Tempat & .113 & .071 & .107 \\
\hline
\end{tabular}

The results of the regression analysis shown in table 4.22 above, can be described regression in the form of a linear equation. The form of the equation is as follows:

$Y=1.301+0.499 X_{1}+0.025 X_{2}+0.065 X_{3}+0.061 X_{4}$

a. The constant a value of 1.301 can be interpreted that without the Product, Promotion, Price, and Place variables, the voter's decision to choose a local party is 1.301

b. a. The coefficient b1 value of 0.499 can be interpreted that every increase in perception of the Product variable by 1 point, it will increase the voter's decision by 0.499 points.

c. The b2 coefficient value of 0.025 can be interpreted that every increase in perception of the Promotion variable by 1 point, it will increase the voter's decision by 0.025 points.

d. The b3 coefficient value of 0.065 can be interpreted that every increase in perception of the price variable by 1 point, it will increase the voter's decision by 0.065 points.

e. The b4 coefficient value of 0.065 can be interpreted that every increase in perception of the Place variable by 1 point, it will increase the voter's decision by 0.065 points.

\section{1) Simultaneous Test}

From the results of the ANOVA or F test, the Fcount value of 48,738 with Ftable of 2,603 means that Fcount > Ftable with a probability of 0.000 is much smaller than 0.05 or $5 \%$ so that it can be interpreted that the Product, Promotion, Price, and Place variables simultaneously 
have a significant effect on the decision. voters to vote for local parties in the 2019 Provincial Elections at the Bireuen and Pidie Jaya Regencies, Aceh Province.

Table. 6

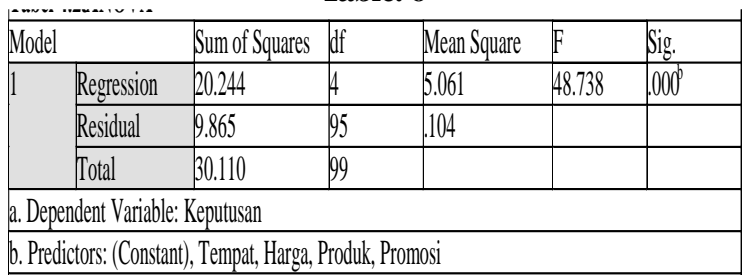

\section{2) Partial Test}

According to the results of calculations using SPSS, it can be concluded that the variables included in the regression model, namely the Product, Promotion, Price, and Place variables partially can be explained as follows:

\begin{tabular}{|l|l|l|l|l|l|}
\hline \multicolumn{7}{|c|}{$\begin{array}{c}\text { Table.7 } \\
\text { Coefficients }\end{array}$} \\
\hline \multirow{2}{*}{ Model } & $\begin{array}{r}\text { Unstandardized } \\
\text { Coefficients }\end{array}$ & $\begin{array}{l}\text { Standardized } \\
\text { Coefficients }\end{array}$ & \multirow{2}{*}{$\mathbf{t}$} & \multirow{2}{*}{ Sig. } \\
\cline { 2 - 5 } & $\mathrm{B}$ & Std.Error & Beta & & \\
\hline 1 (Constant) & 1.301 & .310 & & 4.201 & .000 \\
\hline Produk & .499 & .046 & .741 & 10.793 & .000 \\
\hline Harga & .025 & .089 & .022 & .277 & .782 \\
\hline Promosi & .065 & .063 & .088 & 1.036 & .303 \\
\hline Tempat & .061 & .064 & .064 & .957 & .341 \\
\hline a. Dependent Variable: Keputusan & & \\
\hline
\end{tabular}

a. The results of the research on the Product variable (X1) obtained tcount $=10,793$ while ttable was 1,986 . These results indicate that tcount $>$ ttable with a significance of 0.000 or a probability below 0.05 . Thus the results of statistical calculations show that partially the Product variable (X1) has a significant effect on the Local Party Selection Decision (Y) variable.

b. The results of the research on Promotional Variables (X2) obtained tcount $=1,036$ while ttable was 1,986 . These results indicate that tcount $<$ ttable with a significance of 0.303 or a probability well above 0.05 . Thus the results of statistical calculations show that partially the Promotional Variable (X2) has no significant effect on the Local Party Choosing Decision variable $(\mathrm{Y})$.

c. The results of the research on the Price Variable (X3) obtained tcount $=0.277$ while ttable was 1.986 . These results indicate that tcount $<$ ttable with a significance of 0.782 or the probability is far below 0.05 . Thus, the results of statistical calculations show that partially the Price Variable (X3) has no significant effect on the Local Party Election Decision variable (Y). d. The results of the research on the Place Variable (X4) obtained tcount $=0.957$ while ttable was 1.986 . These results indicate that tcount $<$ ttable with a significance of 0.341 or a probability well above 0.05 . Thus, the results of statistical calculations show that partially the Place Variable (X4) has no significant effect on the Local Party Election Decision variable (Y).

1) Coefficient of Determination (R2)

From the SPSS model summary, the coefficient of determination is 0.672 . This means that $67.2 \%$ changes in the dependent variable, namely the Decision to Choose a Local Party, can be explained in the independent variables, namely Product, Promotion, Price, and Place. While the remaining $32.8 \%$ is explained by other variables outside the variables studied. This shows that the contribution of the independent variable has an impact on the dependent variable.

\begin{tabular}{|c|c|c|c|c|c|c|c|}
\hline \multicolumn{8}{|c|}{$\begin{array}{c}\text { Tabel8 } \\
\text { Model Sumary? }\end{array}$} \\
\hline \multirow{3}{*}{ Model } & \multirow[b]{2}{*}{$\mathbb{R}$} & \multirow[b]{2}{*}{ R Square } & \multirow{2}{*}{ Adjusted R Squar } & \multicolumn{4}{|c|}{ Stdd Error of the Change Statistics } \\
\hline & & & & R Square ChangeF Fhange & dif & de & Sig. FChange \\
\hline & .820 & .672 & \begin{tabular}{|l|l|}
.659 & 32225 \\
\end{tabular} & \begin{tabular}{|l|l|}
672 & 48.738 \\
\end{tabular} & A & 95 & .000 \\
\hline \multicolumn{8}{|c|}{ a. Predictors: (Constant), Tempat, Harga, Produk, Promosi } \\
\hline \multicolumn{8}{|c|}{ b. Depentent Variable: Keputusan } \\
\hline
\end{tabular}

\section{Conclusion}

1. Results of Regression Analysis of the Effect of Product, Promotion, Price, and Place on the Decision to Choose a National Party, namely From the results of the ANOVA test or F test, the Fcount value is 87,851 with Ftable of 2,603 this means Fcount $>$ Ftable with a probability of 0.000 which is much smaller than 0,05 or $5 \%$ so that it can be interpreted that the variables of Product, Promotion, Price, and Place simultaneously have a significant effect on voters' decisions to choose a national party in the 2019 Provincial Elections in the Bireuen and Pidie Jaya Regencies, Aceh Province.

2. Results of Regression Analysis of the Effect of Product, Promotion, Price, and Place on Decisions to Choose Local Parties From the results of the ANOVA or F test, the Fcount value is 48.738 with Ftable of 2.603. This means that Fcount $>$ Ftable with a probability of 0.000 which is much smaller than 0.05 or $5 \%$ so that it can be interpreted that the variables of Product, Promotion, Price, and Place simultaneously have a significant effect on voters' decisions to choose local parties in the 2019 Provincial Elections in the Bireuen and Pidie Jaya Regencies, Aceh Province. 


\section{REFERENCE}

Arep, Ishak, \& Tanjung, H. (2003). Manajemen Sumber Daya Manusia. Universitas Trisakti.

Butler, P., \& Collins, N. (1994). Political marketing: Structure and process. European Journal of Marketing.

Dermody, J., Hanmer-Lloyd, S., \& Scullion, R. (2010). Young people and voting behaviour: alienated youth and (or) an interested and critical citizenry? European Journal of Marketing.

Firmanzah. (2007). Marketing Politik Antara Pemahaman dan Realitas. Yayasan Obor Indonesia.

Ghozali, I. (2013). Aplikasi Analisis Multivariate Dengan Program IBM SPSS 21 Update PLS Regresi (Edisi 7). Badan Penerbit Universitas Diponogoro.

Harris, P. (2001). To spin or not to spin, that is the question: The emergence of modern political marketing. The Marketing Review, 2(1), 35-53.

Lilleker, D. G. (2006). Key concepts in political communication. Sage.

Moloney, K., \& Colmer, R. (2001). Does political PR enhance or trivialise democracy? The UK general election 2001 as contest between presentation and substance. Journal of Marketing Management, 17(9-10), 957-968.

Nursal, A. (2004). Political marketing: strategi memenangkan pemilu: sebuah pendekatan baru kampanye pemilihan DPR, DPD, Presiden. Gramedia Pustaka Utama.

O’Shaughnessy, N. J. (1990). The phenomenon of political marketing. Springer.

Saper, C. B., Cano, G., \& Scammell, T. E. (2005). Homeostatic, circadian, and emotional regulation of sleep. Journal of Comparative Neurology, 493(1), 92-98.

Sugiono. (2014). Metode Penelitian Bisnis. Alfabeta.

Surbakti, R. (1992). Memahami ilmu politik. Grasindo.

Wring, D. (1997). Reconciling marketing with political science: theories of political marketing. Journal of Marketing Management, 13(7), 651-663. 